\title{
A Farewell to Two Major Comparative Scholars
}

This autumn, comparative literary studies lost two remarkable scholars, Interlitteraria's two longtime contributors and friends. To give our readers a chance to say goodbye with us, we reprint the eulogies written by Jüri Talvet for the journal Forum for World Literature Studies (Vol. 7, N. 3, Sept. 2015) and for the book The Traveller. Uncollected Works of Mohit K. Ray (First Wave).

\section{In memoriam John Neubauer (1933-2015)}

On the eve of our Estonian Association of Comparative Literature $11^{\text {th }}$ international conference in Tartu, Estonia, I received an e-mail letter from my long-time good colleague and friend John Neubauer, from Amsterdam. His short lines from September 26, 2015, with the title "Farewell", put me in consternation. With heavy heart, John said, he had to announce his retirement from the academic advisory committee of our journal Interlitteraria, because his death was imminent.

Especially as John sent me his letter by e-mail and was himself an interdisciplinary scholar par excellence, first educated as a physicist, and then as a literary and cultural scholar, with an amazingly broad knowledge and erudition in sciences, music, psychology and history, his tragic announcement made me once more feel the sad truth summarized in its fullest quintessence by Pedro Calderón de la Barca in the short play El gran teatro del mundo ('The Great Theatre of the World'). Whatever wonderful illusions of future and progress man could produce and imagine on earth, whatever roles he might take on, whatever escapes could he scheme, the end is silence. No human mind, however clever, capable or prophetic, can claim to know if what we see during this short symbolic second of our lives, is reality or just a dream.

Yet despite all that the same Spanish $17^{\text {th }}$-century playwright, poet and philosopher set forth in his drama masterpiece La vida es sueño ("Life Is a Dream') the noble leitmotif of "doing good" and following the path of virtue, regardless of what life was. "Even if it is merely a dream, a good and virtuous deed will never be lost”, Calderón claimed.

It can be said of John Neubauer's deeds in his life / dream. We met in Tartu in 1993, shortly after Estonia, following the collapse of the Soviet empire, had become a free independent state. I had been teaching Western literary history at the University of Tartu - Estonia's main university - since 1974. After the country's reestablished independence, in 1991, I was elected to the post of 
chair professor of world literature. In parallel, I was in charge of coordinating a program of Spanish studies, for the first time ever introduced in Estonia.

At the time of John's visit to Tartu, he was an accomplished comparatist, an active member of the International Comparative Literature Association, one of those scholars who had substantially contributed to the research of literature's relations with science, language and music. After leaving his home country Hungary as a young man, after the 1956 uprising and the following repressions, he settled in the US, where he got his academic degrees and taught German literature at different universities. In 1983 he moved to the Netherlands where he worked as the chair professor of comparative literature at the University of Amsterdam.

By contrast with John's international scope of scholarly activities, our Estonian academic life had been very much restricted in the Soviet Union. Our contacts with Western scholarship were scarce. The economic situation of the country at the start of the new independence was extremely poor, our salaries at universities were low. To visit other countries we nearly always needed visas. Lots of efforts had to be made for elementary daily survival, while at the same time there was an urgent need to restructure academic life, to write new manuals for schools and universities, etc.

At our meeting in 1993 John asked us: why could we not found our Estonian association of comparative literature, to become a collective member of the ICLA? Indeed, we liked and accepted his idea. At the end of the same year we founded our Estonian Association of Comparative Literature. Since its admission in 1994 to the structure of the ICLA it not only started to propel literary research in Estonia, but contributed increasingly to the international dimension of our literary life.

Naturally, not everything went so smoothly in the beginning. Our travels abroad were still very much restricted by the economic misery of those times. Thus, evoking today my first ever visit to the Netherlands - following John's invitation for guest lectures at his home university of Amsterdam, in 1994 - it sounds like a series of grotesque adventures of a picaresque novel... As air travel was too expensive for my budget, I and my wife Margit had the plan to reach the Netherlands by bus via Poland and Germany. The Estonian bus failed to appear in the evening of our scheduled departure from Tartu. The boss of the bus firm apologized and promised us air flight from Tallinn airport the following morning. Yet nobody in Tallinn knew anything about that special deal. As a result, my wife had to stay at home, while I bought a one-way air ticket to Amsterdam, with the hope, as the bus firm boss had assured me, that I could still return from the Netherlands by their surface transport. 
However, while in Amsterdam, I had to obtain Germany's transit visa and also the Netherlands return visa, as my plan included proceeding from Amsterdam to Paris, by a Eurolines bus, to visit my sister who was at that time in charge of establishing the Estonian embassy in the French capital city... In conclusion, I had to spend a considerable time of my short stay in Amsterdam visiting various embassies and consular offices. Indeed the Germans were kind enough and issued me their transit visa. In turn, the Dutch officials were reluctant to do what I asked. They advised me not to go to Paris. I still did. Luckily nobody checked my passport during that illegal night travel across the lowlands between France and the Netherlands... I still could not return by bus to Estonia, because the Estonian bus firm meanwhile had gone bankrupt... John was kind and tried to help me as he could, but he could not do much for a post-socialist East-European visitor who clearly did not fit into the system of the Western world. After I had asked somebody in Estonia to lend me money and finally could take my return air flight, I felt as if I had fled from a "living hell"...I was happy to be back in my poor and miserable native country.

Gradually we managed to overcome these initial difficulties of the new independence phase of our state. Our country established its institutions and foundations that, however modestly, still provided some relief for cultural and academic activity. In 1996 we founded Interlitteraria, an international comparative literature journal. By today, it has become an important platform for European and world literary and cultural research. Also in 1996, we held in Tartu our first international comparative literature conference. Our scholars started to take part in the worldwide activities of the ICLA, while our efforts to contribute to the international field of comparative literary studies were appreciated and supported by a number of leading and merited world scholars whose articles and essays started to appear in Interlitteraria, in parallel with contributions of younger literary researchers from a great variety of countries.

John Neubauer belonged, in the ICLA and in the comparative research field, to the minority of international scholars who dared to undertake major tasks. In my opinion one of his greatest achievements was editing, with Marcel Cornis-Pope, a four-volume History of the Literary Cultures of East-Central Europe (2004-2010), to which all active literary and cultural scholars from our part of the world were invited to contribute. More than ever before and after our Estonian literary researchers became involved in the collective ICLA project of writing a new literary history, organized in a novel fashion, with a number of historical nodes as points of departure for discussing all major EastCentral Europe's literary-cultural issues and phenomena.

In his article "Globalizing Literary History" published in Interlitteraria (181/ 2013), John Neubauer shared with world comparatists the rich experience 
acquired by the editors in the long process of organizing and shaping this new experimental literary history. He did it in the context of all existing previous efforts in the mentioned field, as well as envisaged contours for those younger scholars who might undertake similar efforts, not only in the Western part of the world, but also in the East, in times to come.

John was open to new ideas and approaches, but he was far from sticking to certain "schools" or positions, which unfortunately have led an important section of comparative literary scholarship to follow either formalist or sociological patterns, in oblivion of the primary moral tasks humanities have in the world. He welcomed the formation in China of a new movement of ethically orientated literary research and the foundation of the International Association of Ethical Literary Criticism. Time appeared implacably too short for John to contribute in person to the conferences of this newly founded association.

Yet moral orientation of literary criticism was by no means anything new for John. I guess his last article published in his life was under the title "Victims and Perpetrators: Two Novels on the 1942 Novi Sad Atrocities", printed in Interlitteraria's special issue Taming World Literature, presented in Tartu just a few days before the great scholar and kind friend John Neubauer passed away.

Thank you, dear John. We in the Estonian academia of literary scholarship will remember you forever. You indeed did good deeds to us and the world of letters.

Jüri Talvet Tartu, October 10, 2015 
Thinking of Mohit K. Ray (1940-2015), from "periphery" to "periphery"

If my memory does not fail me, I met Mohit for the first time at the ICLA world congress in Leiden, the Netherlands, in the hot summer of 1997. It was Saturday. We sat a while together conversing with a glass of beer at a main street café. A bizarre crowd passed by, until following the country's Protestant habits, exactly at $6 \mathrm{pm}$ all shops and restaurants closed and quiet overwhelmed the Dutch city with its typical romantic channels.

I came from Europe's North-Eastern periphery, Estonia, a tiny country that in 1991 thanks to the spectacular collapse of the USSR could restore, as a state and a nation, the ephemeral independence it had enjoyed between the two $20^{\text {th }}$-century World Wars. The Western life-style was in those times still new for us. Especially our younger literary scholars tried at any cost to adapt to the postmodern theory which was in its full vogue then in the Western "centers".

To be honest, it was really the first time I spoke with anybody from India and any Indian scholar. (Besides Mohit, there were more people from India attending the congress.) I noticed immediately their kind, pleasantly polite and attentive manner. We easily found a common language between us, because we all had come to attend a major academic event in the Western "center" from some "periphery", small or large. I spoke to Mohit - who being five years older than I was, and by that time an established and mature scholar - of the plans we had in Estonia to expand our comparative literary scholarship. Mohit immediately agreed to collaborate: he was willing to join our international conference in Tartu, the main Estonian university town where I worked, as well as to contribute to Interlitteraria, founded a year earlier.

Mohit was twice our guest in Tartu, in 1998 and 2001. In those times our Estonian national press still paid some attention to literary events like those organized by the Estonian Association of Comparative Literature (EACL). A picture taken of Mohit at the opening of the conference was published in Estonia's major daily paper Postimees. I mention the fact because in the subsequent years such interest on part of the public media symptomatically narrowed and died down. The "periphery", once awakened and open to a possibility of a spiritual change, became gradually fully homogenized with "centers" where the public media, dominated by mass culture, long ago had stopped to pay any attention to such "useless", "unprofitable" and "unattractive" activities as literary scholarship.

Also, as an independent state, Estonia rapidly developed its own bureaucracy. Mohit's intended third visit to Tartu was jeopardized by bureaucratic hurdles. 
Despite the above said, our Tartu conferences have continued. Mohit was among those internationally renowned scholars who helped especially in the initial stage of our activity to make us visible in the European and world academic arena. Above all Mohit's presence stands out in Interlitteraria. All in all his contributions to Interlitteraria include seven valuable articles or essays, the earliest being "Derrida and the Indian Theory of Language" $(3,1998)$ and the last, "Humanism and Rabindranath Tagore" $(16 / 1,2011)$. It is no exaggeration to say that among international comparative literature scholars Mohit was in the forefront of those who built up Interlitteraria's prestige as an open forum for dialogue and exchange of ideas between West and East, "peripheries" and "centers".

Mohit was a comparative scholar par excellence, from the very basis of his admirable linguistic knowledge. He knew several of the principal languages of the Western "center" (English, French, German, Latin) as well as a number of Oriental languages (Sanskrit, Hindi, Arabic, besides his native Bengali). The openness to the world cultural heritage and to modern creativity was something absolutely natural for him. For that reason in his above mentioned article "Derrida and the Indian Theory of Language" he could voice his optimism about the postmodern turn and the novelty of ideas of the Frenchman Jacques Derrida, one of its main architects. Mohit compared the intellectual turn of the last quarter of the $20^{\text {th }}$ century with "Copernican revolution in the fields of Philosophy, Linguistics and Literary Criticism” (op. cit. p. 76).

Yet as I read again Mohit's subsequent essays in Interlitteraria, I can notice a hidden reserve, very much in the same line with my own skepticism as regards postmodern theory and practice. By the second decade of the new millennium it has become ever more evident that postmodern theory, instead of offering to the world academia new perspectives of spiritual openness and diversity has become itself a highly dogmatized "grand narrative", a fully institutionalized type of culture, a monologue deeply rooted in the Western "center". It has shown its ignorance as regards the spiritual needs of the larger part of the world's "other", including not only its smaller and "peripheral" nations and communities, but also numerous vast and old areas of culture, like the communities of India, China, Indonesia, etc., whose native languages are other than English or French.

I guess a mild hint at the possibility of postmodernism's deviation from its initial promises and potentiality could be found in Mohit's comparison of Jacques Derrida's language philosophy with the views on the language by Raja Bartrihari (more than ten centuries before Derrida). Whatever the details, Bartrihari's śabdatattva or the Word-Principle can hardly be dissociated from the Indian imagination of a deeper sacred origin of existence, Brahman-nada 
(sound absolute) and the god Brahma in whom the world is identified with sound.

By contrast, Derrida's point of departure was hardly other than his compatriot René Decartes's ( $17^{\text {th }}$ century) famous creed that the world of thinking or, the mind's world, was the only reliable and true one. It goes without saying that such a creed would eliminate a dialogue with the "other" in its very bud. It is a radically anthropocentric view on the world, in which anthropos is clearly identified with the human male species (as it had been predominantly in the dogma of the Western Christian church). By the way, Bartriihari, either he was or not the poet of the same name, wrote is linguistic treatise in verse.

Poetry was always close to Mohit's heart. I don't think the mainstream theoretical current of postmodernism would feel comfortable with the rasa of poetic and artistic creation exposed by Mohit in another substantial philosophical meditation in Interlitteraria, "Rasa and Pleasure" (12, 2007). The Indian sages of the past, from Jesus Christ's coeval Bharata to the medieval poetics understood rasa as a natural and spiritual wholeness and unity of artistic creation. Postmoderns, on the contrary, have excelled in clever artificialities and word techniques, in rewriting and intentionally distorting the natural and the spiritual. In "Tradition and Avant-garde in Girish Karnad's Hayavadana" (Interlitteraria $7 / 1,2002)$ Mohit accentuates the longing for a unity of body and mind in the Indian story, in contrast with Thomas Mann's conscious (and exaggerated) separation of these two basic dimensions in humans.

In many ways, Mohit's ideal uniting poetry and wisdom (philosophy) seems to have been the work of his great compatriot Rabindranath Tagore. Departing from a queerly disfigured image of humanism in some of the writings of Michel Foucault - another forefather of Western postmodern thinking postmodern disciples have launched a fierce attack on humanism. Mohit on his part does not hesitate to call things with their right names. According to him, Tagore followed in the footsteps of creative humanistic writers and the greatest poets of both West and East. They were inspired by the spirit of love, above all - love to humans as well as to all living nature of which humans are part. They rejected all racial, social or religious tyranny, discrimination, sectarianism, pedantry, humiliation and violence. They searched for freedom, human dignity and peace.

Mohit's humanism also explains his mediation in the publication in India of one of the few anthologies ever published of Estonian poetry in English translation and thus, establishing a spiritual bridge between the wider world, his country, India, and our small European peripheral nation, Estonia. To resume my homage to the late friend and colleague, let me quote his generous 
A Farewell to Two Major Comparative Scholars

words from the book On the Way Home. An Anthology of Contemporary Estonian Poetry (ed. H. L. Hix, New Delhi: Sarup \& Sons, 2006):

Since 1991 when Estonia became independent we have a fresh flowering of Estonian poetry combining traditional themes of the land and the people, their trials and tribulations, and a modern note of the scars of the cultural memory, untiring intellectual quest and cultural nationalism. The poems in the anthology secure for Estonian poetry a permanent niche in the world poetry for their range and depth, richness and variety of form, as well as the substance and quality of vision.

Thank you, dear Mohit, a warm-hearted and poetically minded friend who carried into future the best tradition of comparative literary studies and creative humanism.

Jüri Talvet

Tartu, November 9, 2015 